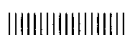

\section{特 集 信頼性解析・リスク解析へのファジィの応用}

\section{品質保証システムとファジィ}

\section{長沢 伸也*}

\section{1. 緒 言}

今日の我が国の企業、とくに製造業に扔ける大 きな課題として、円高対策や不況対策とともに、 ISO 9000 シリーズによる国際的認証制度への対 応と PL (product liability; 製造物責任)の立法化 への対応が挙げられよう。

ISO 9000 シリーズに基づく国際的認証制度と は、企業の品質保証システムをISO(国際標準化 機構) 規格で認証する制度である。EC 加盟国をは じめ海外へ製品を輸出する際には、この認証を企 業(製品でないことに注意)が取得していることが 要求されることが多くなっている。つまり、この 認証を取得していないと海外入の輸出が困難にな るので、産業界を挙げて取り組んでいる。

PLに関しては、米国、ECなどで既に導入され ており、とくに米国においては社会問題化してい る。我が国においても立法化が検討されており、 米国並の訴訟社会になることを恐れる産業界の猛 反対によって今のところは見送られているものの、 ここ一、二年中の立法化は必至である。

ISO 9000 シリーズによる国際的認証制度も PL も品質保証の問題であるが、品質保証は実は 信頼性の考え方によっている。

そこで、本稿では、品質保証あるいは品質保証 システムについて解説し、これにファジィ理論を 応用した例を紹介する。

$†$ Quality Assurance System and Fuzzy Sets Theory

* Shin'ya NAGASAWA

覀細亜大学 経賞学部

Faculty of Business Administration, Asia University

\section{2. 品質保証の定義}

まず、品質保証 (quality assurance, QA) とは何 かについて、JIS(日本工業規格)および ISO(国際 標準化機構)による定義を見てみよう。

JIS Z 8101 品質管理用語 では、次のように定 義されている；

「消費者の要求する品質が十分に満たされてい ることを保証するために、生産者が行う体系的 活動」

これに対して、ISO 9000“Quality management and quality assurance standards”では、次のよ うに定義されている；

「製品又はサービスが、所与の品質要求を満た していることの妥当な信頼感を与えるために必 要なすべての計画的及び体系的活動。

備考 1 . 所与の品質要求が、顧客の要望を十 分に反映したものでなければ品質保証 は完全ではない。

備考 2. 品質保証を効果的に行うためには、 意図した用途のための設計又は仕様の 妥当性に影響を与える要素を常時評価 するとともに、製造、据付け、及び検 查作業の検証及び監査が必要となるの が普通である。信頼感を与えることに 証拠を残す活動を含めてよい。

備考 3。組織の内部では、品質保証は経営の 一つの道具となる。契約による場合に は、品質保証は供給者に対する信頼感 を購入者に与えるのに役立つ。」

これらの定義からわかるように、品質保証は体 
系的に行われる必要がある。したがって、JISや ISO にはとくに定義されてはいないが、この品質 保証の体系が品質保証システムということになる。

なお、上述のように、品質管理及び品質保証の ための一連の国際規格である ISO 9000 シリーズ （ISO 9000～9004）は、現在世界中に普及が進みつ つある。これらの規格は、既に 40 以上の国で国家 規格として採用され、そのうち約 30 か国では同シ リーズ規格を基準文書とする品質システム審査登 録制度が創設されており、今後も更に普及が進む ものと予想される。

特に、1993 年からの市場統合により製品の流通 の円滑化を目指している EC 諸国では、ISO 9000 シリーズ規格に基づく品質認証を域内で統一して 実施するべく、多くの国で品質システム審査登録 制度が創設され、民間審査機関間の相互認証など も進みつつある。

また、いくつかの国では、政府物資の調達に当 たって納入企業に対して品質システムの義務付け を行いつつあるが、その際に ISO 9000 シリーズ 規格に適合する品質システムをもつことを要求す る場合も生じている。一方、同様に企業間の調達 においても、同シリーズ規格による品質保証を要 求する例が急速に増えている。

こうした国際動向に対し、我が国としても的確 に対処するため、JIS Z 9900～9904の 5 規格が、 ISO 9000 シリーズ規格の完全翻訳として制定さ れている。上揭のISO による品質保証の定義の訳 はこれによっている(JIS Z 9900～9904 品質管理 及び品質保証の規格)。

\section{3. 品䨘保証亡品覧管理}

品質保証と似た言葉に品質管理がある。 品質管理 (quality control) は、JIS Z 8101 によ ると次のように定義されている；

「買い手の要求に合った品質の品物又はサービ スを経済的に作り出すための手段の体系。品質 管理を略して QC ということがある。また、近代 的な品質管理は、統計的な手段を採用している
ので、特に統計的品質管理 (statistical quality control, 略して SQC) ということがある。品質 管理を効果的に実施するためには、市場の調查、 研究・開発、製品の企画、設計、生産準備、購 買・外注、製造、検查、販売及びアフターサー ビス並びに財務、人事、教育など企業活動の全 段階にわたり、経営者を始好管理者、監督者、 作業者など企業の全員の参加と協力が必要であ る。このようにして実施される品質管理を全社 的品質管理 (company-wide quality control, 略 して CWQC) 又は総合的品質管理(total quality control, 略して TQC) という。」

我が国の品質管理は戦後製造業を中心に導入さ れたが、1980 年代には一種の QC ブームとも言う べき傾向が現れ、多くの業種が導入を図り、一般 のマスコミまでもが QC を取り上げ、世界中から 注目されるところとなっている。

品質保証と品質管理の関係について、一般的に よく言われることは、「品質管理は、品質保証を達 成する手段である」ということであろう。すなわ ち、品質保証を目的とし、品質管理をその手段と している。これは、1950 年代後半の TQC 導入時 代に品質管理を極めて広く解釈し、製品品質の管 理面が薄れてしまったという傾向に対する反省と して、製品品質の管理を強調するために「品質保 証」という言葉が好んで用いられたという経緯に よるものと考之られる。すなわち、我が国では、 品質保証といえば、製品またはサービスの品質を 達成するための活動を意味し、品質管理といえば、 主として QC 手法ならびに考え方を適用した活動 をさし、それらの手法・考え方は単に製品品質の みならず、生産量管理、販売管理、利益管理など の経営の諸活動にも活用できるという立場で使わ れることが多いといってよいであろう1。

品質保証システムは、企業の形態、製品の種類 によってかなり内容、表現が変わってくるため画 一的に表せないが、JISにおける品質管理や TQC の定義にあるように、社内各部門の相互関係が緊 密に連携し合って初めて製品品質の維持・向上が 達成されるのである2。 


\section{4. 品質保証の歴史的発展}

従来、品質保証については、いろいろの䛊解が あった。たとえば、

(1) 検査を厳重にしていれば、品質保証を行ってい る

(2) 不良品だったら無料で良品と交換すればよい

(3) ある期間無償で修理すれば、品質保証を行って いる

などという愦りである。(2)，(3)補償の責任をも っているのであって、保証しているわけではない。 歴史的には、品質保証、品質管理の基本は検査 にあった。これが戦前の品質管理であった。現在、 海外において、まだ検査＝品質管理と思っている 人も多い。しかし、検査だけでは品質保証できな いし、また不利であるということが次第に明らか になってきた。たとえば、

(1) 全数検査を行っても検查ミスなどにより不良 品が出荷されていく

(2) 破壊検査や耐久性テストのように、全数検査で きないもの、あるいは不経済なものがある

(3) 全数検査で不良品を完全に除去しても、その不 良品の手直し費やスクラップ代はロスになり、 工数がかかるばかりで不経済である

(4) 手直しや調整した製品は不良になりやすい

(5) ある特性 (主として代用特性)について全数検 查できても、その製品の真の品質特性がよいか どうかがわからない

そこで「品質は製造工程で作り込め」ということ になって、工程管理を行うことによって品質管理 を行う方が有利である、工程管理がうまく行われ 全数良品になれば検査費用は不要になるではない かということになってきた。これが戦後、我が国 で新しい品質管理の始まった時代の品質保証の考 え方であった。

さらに、消費者が不満に思っていても、それを 泣き寝入りしていたり、あるいは苦情を言っても その情報が必要とする人のところへ届かなかった りすることが明らかになったので、「プロダクト・
アウト (殿様商売)の時代からマーケット・イン (消 費者は王様)に」などということが強調され、どこ が品質保証されていないかを明らかにする活動が 行われた。すなわち、消費者の欲するところ、不 満に思っているところを探して品質保証していこ うという、消費者指向の品質保証が行われるよう になってきた。

ところが、実際にやってみると、これでもなか なか不良は減らないし、消費者からの苦情も減ら ない。その理由は、

(1) 新製品開発のやり方がまずく、設計・試作がま ずいと、いくら頑張っても製造工程で不良をゼ ロにすることは困難あるいは不可能である

(2) 信頼性、耐久性については、製造工程をいくら 管理しても無理で、新製品開発の時期にしっか りしたテストを行っておくか、さらに信頼性に ついては、しっかりした研究、長い技術の蓄積 および標準化が行われていないと保証は困難 である

ということがわかってきたからである。これが 1950 年代後半、1960 年頃である。

そこで、「設計と工程で品質を作り込め」「新製 品開発の品質保証」ということが強調されるよう になってきた。そして信頼性の研究が行われだし てきたし、日本製品の信頼性も徐々に向上してき た。

1960 年代後半から米国において、1970 年代に入 ってから我が国においても、PL(製造物責任)のこ とが問題になってきて、欠陥商品を出さないよう にすることはもちろんのこと、消費者の誤用、過 信用によって起こるトラブルの防止、いいかえる と安全と人命尊重にもっと重点をおいた品質保証 をしなければならないという時代になってきた。

以上のように、品質保証をうまく行うための態 度ややり方は次第に進歩発達してきたのである3。

\section{5. 品筫保証の意雄}

品質保証は、その仕事が研究開発、設計及び製 造の各段階において順調に進行されているときに 
は、それが重要なものであることは認識されにく い。むしろ、品質保証のために、品質向上のため の投資をしたり、品質管理の教育を行うことは、 費用を無駄使いしているように考えがちであるが、 ひとたび、品質上の失敗が顕在化すると企業は莫 大な損失を被ることになり、品質保証の十分でな かったことが悔やまれることになる。

品質保証は、まず欠陥の防止という役割を持つ。 ちなみに、品質の失敗による PLにより、米国にお いては最近では 1 件数十億円の損害賠償請求が発 生し、しかも急增しているという。1960 年代の前 半の消費者主義の発達の延長線上に、1970 年代に はPL 問題という課題が提起され、信頼性が品質 保証の中で重要な役割を担うようになったといえ よう。

なお、PL (product liability; 製造物 (賠償) 責 任、製品責任)は、JIS Z 8101 では次のように定義 されている;

「設計、製造もしくは表示に欠陥がある製品を 使用した者、又は第三者がその欠陥のために受 けな損害に対して、製造業者や販売業者が負う べき賠償責任」

また、品質保証は欠陥を防止することだけでは なく、ユーザーニーズによって把握された顧客の 要求によく適合した仕様の品質の製品を作り出す ためにも重要な役割を有するようになったことも 忘れてはならない。すなわち、当り前品質(充足さ れれば当り前と考えるが、不充足であれば不満を 引き起こす品質要素)を保証するだけではなく、魅 力的品質 (充足されれば満足を与えるが、不充足で あっても仕方ないと受け取られる品質要素)をも その保証の対象としてきたのである。近年、品質 機能展開などもよく用いられるようになってきた のも、このような動きに応える新しい品質保証の 動きである4)。

\section{6. 品筫保証と人}

製品はすべて人がつくり、人が使うのであるか ら、人間と品質保証とは切っても切れない深い関
係がある。

設計者がしっかりしていなければ、多量の欠陥 事故を起こすであろうし、作業者がしっかりして いなければ欠陷商品が続出になろう。

一方、消費者が説明書や注意書をよく読んで使 用してくれなければ、その製品は性能を発揮でき ず、品質保証できないのみならず、警告などを無 視すれば、火災になったり、怪我をしたり、病気 になったり、場合によっては死亡事故すら起こす ことになり、PL 問題になる5)。

品質保証は、品質保証のために投資をしたり、 無駄な費用を増やすものであると䛊解されること がある。真の品質保証は市場のニーズと品質の情 報を正しくとらえて、これに応える組織活動であ る。

ある技術者は、不況で売上が減少したため、営 業部門へ応援に出ることとなり、市場の実状を肌 で感じて、それまでの営業部門から入手していた 市場の品質情報は勾の情報であったことに初めて 気づいたという話がある。品質保証の体系と品質 情報の収集体系を作るのは人であり、それに活力 を与えるのも、これまた人なのであるから、体系 を作ったというだけでは品質保証はできない。

また、品質は顧客のためにあるので、顧客の品 質とは何かをよく考える必要がある。この品質の 意味が明確になったらこれを尺度として品質を評 洒し、活動につなげることがマーケット・インの 品質保証となる ${ }^{6)}$ 。

品質保証や品質管理を進めるのも人間であるし、 マーケット・インする相手である顧客も人間であ る。いずれにしろ、人間社会における製品であり、 品質保証であるから、人のことを考えないで品質 保証は考えられない。

\section{7．品簤保証・品筫管理とファジィ}

「品質管理は、品質保証を達成する手段である」 ということは前述したが、多くの業種に導入され、 世界中から注目されるところとなっている我が国 の品質管理 (日本的品質管理とも呼ばれる)では、 
「経験と勘と度胸」のやり方を否定し事実(デー 夕)でものを見、解析することが重要であるといわ れている。そこで、「主観やあいまいさはいけない ものだ」と思われがちであるが、本当にそうだろ うか。

たとえば、SQC(統計的品質管理)に必要な統計 手法では、計算そのものに主観やあいまいさの入 る余地はない。しかし、実施場面では、変数選択 型重回帰分析等における変数選択や、分散分析に おける誤差のプーリングの問題などのように、計 算の前後の処理において解析者が有する固有技術 上の知見が統計解析のモデル構築の過程や結果の 解釈などに大きな影響を与える場合が多い。

また、事務・営業・研究開発などの部門では、 数值データが得られにくく主観的なデータがほと んぞである。そこで TQC (全社的品質管理)では、 こうした「言語データ」を扱う手法として、新 $\mathrm{QC}$ 七つ道具や品質展開のように、必ずしも純粋な統 計手法とはいいがたい手法も多用されている。し かし、これらの手法にもあいまいさがある。

また、社会全体が「人間重視・生活重視」の動 きにあり、「感性」がキーワードとして多用される ようになってきているため、感性品質を特性值と することが多くなっている。多くの事例では、チ エックリスト的に加算したり、重視度のウエイト と充足度のウエイトの積を合計したりする線形評 価が用いられているが、これが必ずしも保証され ているわけではない。

以上のように、新 $\mathrm{QC}$ 七つ道具や品質表等はも ちろん、統計手法においても感性のような主観的 なあいまいさを含む場合や固有技術的な判断に頼 らざるをえない場合が多い。

結局、品質管理では、各種手法はあくまでも手 段なのであって、既得の固有技術から出発し、そ のブラシュアップを図ることが目的なのではない だろうか。

統計的品質管理では、「主観あるいは経験・勘・ 度胸はいけない。客観的なデータでモノを言え。 そのためには統計手法を活用せよ」といわれる。 その一方で「固有技術は重要だ」ともいわれる。
しかし、これは矛盾していないだろうか。固有技 術とは、熟練者の主観的な経験・勘やコッのこと ではないだろうか。

従来の経営学でいわれている経営管理論は、経 営計画、経営組織等について、大所高所から経営 のあるべき姿を追求しているが、それらの計画を 下部組織にどう具体的に展開し、日常業務として どう実施し、その結果をどうチェックし、どうア クションをとっていくかという点については具体 性を欠いていた。この点について、TQCの考之方 はより具体的、実践的であるという特徵を持って いるとされる7。

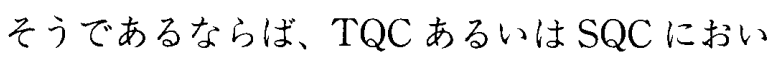
ては、感性や固有技術のような主観的なあいまい さをより具体的、実践的に各種手法に取り込む必 要があるのではないか。

現在のところ、人間の主観による判断やあいま いさを扱えるのはファジィ理論が唯一である。し たがって、品質管理における各種手法にファジィ 理論を取り込んで改良したり拡張したりする必要 があると著者は考える8 。

\section{8. 品質保証のための品質機能展開への ファジィ理論の応用}

上述のように、解析者が有する固有技術上の知 見が重要であったり、事務・営業・研究開発など の部門では主観的なデータがほとんどであったり するので、人間の主観やあいまいさを品質管理へ 取り込むことを積極的に行う必要があり、その方 法論としてファジィ理論を応用する必要がある。

以上の観点から、主観による判断やあいまいさ を伴うために定量的な解析が困難あるいは厳密で なかったさまざまな品質管理的な問題について、 著者は、ファジィ理諭の適用方法をこれまで日本 品質管理学会、米国品質管理学会、日本ファジィ 学会、日本経営工学会の研究発表会やシンポジウ ムなどで提案してきた9)。

本稿では、とくに新製品開発段階からの品質保 証を実現する具体的な方法論として活用されてき た品質機能展開へのファジィ理論の適用方法の概 
要を述べる。

\section{1 品質機能展開とは}

品質機能展開は、顧客の要求を把握し、顧客の 要求からスタートして、それを製品に作り込むま での一連の活動であり、品質保証のための具体的 なシステムである。

顧客の要求は言葉で表現されるため、そのまま では設計ができない。そこで顧客の要求を技術特 性に変換することが必要となる。顧客の真の要求 品質を営業部門が中心となって把握し、把握され た顧客の情報を分析・加味して企画品質を設定し、 それを作り込む活動を設計の意困を理解した生産 技術部門が担当する。この一連の作業が組織的に 実施されることが必要である10)。

顧客の要求を代用特性に変換し、製品の設計品 質を定め、これを各機能部品の品質、更に個々の 構成部品の品質や工程の要素に至るまで、それら の関連を明確にしながら、系統的に展開していく ことを品質展開という。

品質展開の概要を図 1 に示す。

この品質自体の連鎖体系を品質展開システムと いい、品質機能の展開 (品質を達成する職能ないし

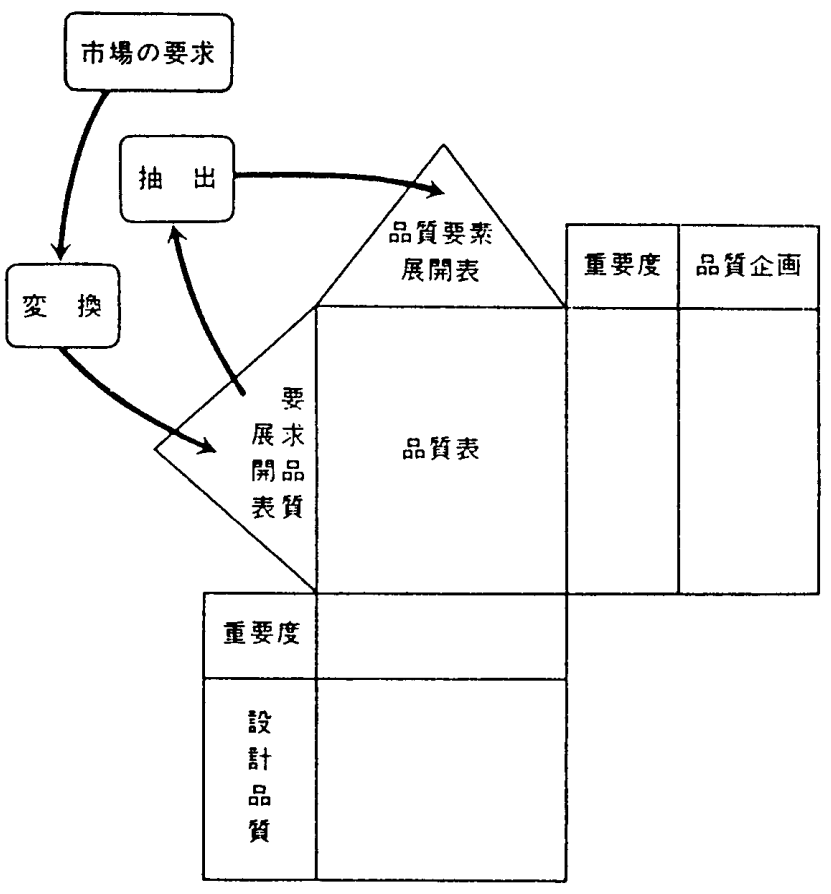

図1 品質展開の概要 ${ }^{10)}$
業務の系統的細部展開) と合わせて品質機能展開 と呼ばれる。

品質展開では、まず顧客の要求を収集し、分類・ 整理して要求品質展開表を作成する。ついで、各 要求項目ごとの代用特性を列挙・整理して要求特 性展開表を作成する。これらを二元表の形に組合 わせて相互の対応関係を明確にしたものは狭義の 品質表と呼ばれ、要求品質を代用特性に変換する 働きをもつことから、設計品質を定めるのに用い られる。品質特性展開表と構成部品展開表を二元 表の形にまとめて相互関係を表したものが広義の 品質表であり、これらを品質展開表と総称する。 さらに工程の諸要素に展開し、最終的には、QC工 程困および作業標準に結びつける。品質展開表と $\mathrm{QC}$ 工程図を結合する諸表を狭義の QA（品質保 証) 表と呼び、QC 工程図・管理標準・業務の機能 展開表・品質保証活動一覧表などを含めて品質機 能展開表という ${ }^{11)}$ 。

\section{2 要求品質重要度の算出へのファジィ構造 モデルの適用}

要求品質展開表の各要求品質に対して、顧客の 要求の程度を表す指標である要求品質重要度を求 める必要がある。その方法としては、顧客に対し て新たにアンケート調査を実施する方法もあるが、 新規開発型商品の場合には AHP (Analytic Hierarchy Process)による方法がある。AHPによる 算出方法の例として、「100 円ライター」における 要求品質 1 次項目を取り上げる ${ }^{12)}$ 。

これに AHP を適用して一対比較值が表 1 のよ うに与えられた場合、重要度の順位は図 2(a)のよ うになるとされる。しかし、判断の整合性を久く ため、整合度および整合比はともに大きく、実は AHP を適用することができない。したがって、重 要度の順位は単純に図 2 (a) とは断定できない(む しろ誤りである) ${ }^{13)}$ 。

そこで、著者は、ファジィ構造モデル(Fuzzy Structural Modeling)により解析することを提案 している。ファジィ構造モデルは、システムを構 成する要素間の相互のあいまいな関係からシステ 
ムを定性的に表現する手法である。この場合は、 個々の品質要素間の重要さの関係から、品質要素 全体としての重要さの構造を多元的に表現する。

ファジィ構造モデルでは集合 $S=\left\{s_{1}, s_{2}, \cdots, s_{n}\right\}$ の要素間のファジィ 2 項関係に関するメンバー シップ関数 $f_{r}, f_{\bar{r}}$ 式(1)で定義し式(2)の関係を 与える。

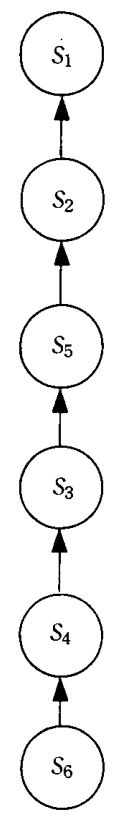

(a) AHP

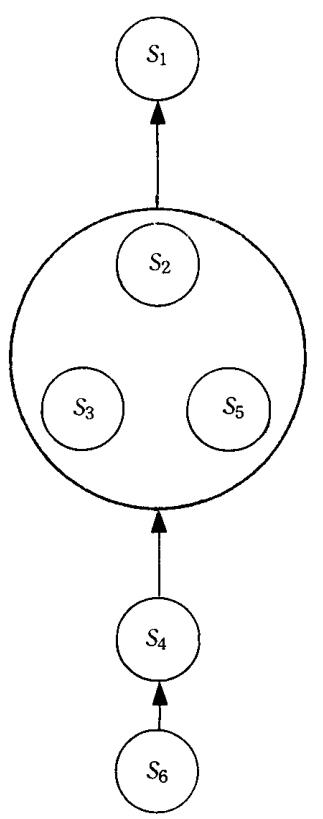

（b）ファジィ構造モデル $(p=0.6, \lambda=0)$
図2適用例における重要度の階層構造 ${ }^{16)}$

$$
\begin{aligned}
& f_{r}, f_{\bar{r}}: S \times S \rightarrow[0,1] \\
& f_{\bar{r}}=\frac{1-f_{r}}{1+\lambda f_{r}}, \quad-1<\lambda<\infty
\end{aligned}
$$

閾值 $p$ が半開区間 $(0,1]$ の実数であらかじめ与え られたとき、ファジィ非反射律およびファジィ非 対称律を満たすように設定されたファジィ従属行 列 $A$ をファジィ半推移律を満なすように修正す るため、式(3)のファジィ合成により $A^{k}$ を求めて、 式(4)によりファジィ半可到達行列 $A^{*}$ を求める。

$$
\begin{aligned}
& A^{k+1}=A^{k_{\circ}} A, \quad k=1,2, \cdots, n-1 \\
& A^{*}=\left[a_{i j}{ }^{*}\right]=A \vee A^{2} \vee \cdots \vee A^{n}
\end{aligned}
$$

そして、ファジィ代数を利用した所定の手順と演 算によりシステムの構造化を行いファジィ構造グ ラフを作成する ${ }^{14), 15)}$ 。

表 1 をファジィ構造モデルにより解析するため、 表 2 によりメンバーシップ関数を対応付けて次の ファジィ従属行列 $A$ を得る。

\begin{tabular}{|c|c|c|c|c|c|c|}
\hline$i$ & $s_{1}$ & $s_{2}$ & $s_{3}$ & $s_{4}$ & $S_{5}$ & $s_{6}$ \\
\hline$s_{1}$ ：確実に着火する & 1 & $1 / 5$ & $1 / 5$ & $1 / 3$ & $1 / 5$ & $1 / 7$ \\
\hline$s_{2}:$ 使いやすい & 5 & 1 & 3 & $1 / 3$ & $1 / 5$ & $1 / 5$ \\
\hline$s_{3}$ : 安心して携带できる & 5 & $1 / 3$ & 1 & $1 / 5$ & 5 & 1 \\
\hline 裈：長い間使用できる & 3 & 3 & 5 & 1 & 3 & $1 / 3$ \\
\hline$S_{5}$ ：良いデザインである & 5 & 5 & $1 / 5$ & $1 / 3$ & 1 & $1 / 5$ \\
\hline$S_{6}$ ：愛着が持てる & 7 & 5 & 1 & 3 & 5 & 1 \\
\hline 幾何平均によるウエイト & 0.46 & 0.16 & 0.11 & 0.07 & 0.15 & 0.04 \\
\hline 固有ベクトル & 0.41 & 0.19 & 0.14 & 0.06 & 0.17 & 0.04 \\
\hline 重要度の順位 & (1) & (2) & (4) & (5) & (3) & (6) \\
\hline
\end{tabular}

$$
A=\begin{gathered}
s_{1} \\
s_{2} \\
s_{2} \\
s_{3} \\
s_{4} \\
s_{5} \\
s_{5} \\
s_{6}
\end{gathered}\left[\begin{array}{cccccc}
0.0 & 0.3 & 0.3 & 0.4 & 0.3 & 0.2 \\
0.7 & 0.0 & 0.6 & 0.4 & 0.3 & 0.3 \\
0.7 & 0.4 & 0.0 & 0.3 & 0.7 & 0.5 \\
0.6 & 0.6 & 0.7 & 0.0 & 0.6 & 0.4 \\
0.7 & 0.7 & 0.3 & 0.4 & 0.0 & 0.3 \\
0.8 & 0.7 & 0.5 & 0.6 & 0.7 & 0.0
\end{array}\right]
$$

表1「100円ライタ一」における要求品質1次項目の $\mathrm{AHP}^{16)}$

最大固有值 $=8.14$, 整合度 $=0.43$, 整合比 $=0.34$

表2 AHPとファジイ構造モデル(FSM)の一対比較值の対応づけ

\begin{tabular}{c|ccccccccc}
\hline 手法 & \multicolumn{10}{c}{ 一 対 } & 比 & 較 & 值 & & & \\
\hline AHP & $1 / 9$ & $1 / 7$ & $1 / 5$ & $1 / 3$ & 1 & 3 & 5 & 7 & 9 \\
FSM & 0.1 & 0.2 & 0.3 & 0.4 & 0.5 & 0.6 & 0.7 & 0.8 & 0.9 \\
\hline
\end{tabular}


閾值 $p=0.6$, ファジィ構造パラメータ $\lambda=0$ と して、ファジィ合成によりファジィ半可到達行列 $A$ *を求めると次のようになる。

$$
A^{*}=s_{s_{2}} s_{3}\left[\begin{array}{cccccc}
s_{1} & s_{2} & s_{3} & s_{4} & s_{5} & s_{6} \\
s_{4} & s_{5} \\
s_{5} \\
s_{6}
\end{array}\left[\begin{array}{cccccc}
0.7 & 0.3 & 0.3 & 0.4 & 0.3 & 0.2 \\
0.7 & 0.7 & 0.6 & 0.4 & 0.6 & 0.3 \\
0.7 & 0.7 & 0.7 & 0.3 & 0.7 & 0.5 \\
0.7 & 0.7 & 0.6 & 0.6 & 0.7 & 0.6 \\
0.8 & 0.7 & 0.6 & 0.6 & 0.7 & 0.3
\end{array}\right]\right.
$$

$A^{*}$ において 2 個以上の主対角成分が $p$ 以上の値 であるならば、強連結集合が存在する。ここで、 強連結集合とはサイクリックパス(ある要素 $s_{i}$ が 他の要素を介して間接的に $s_{i}$ 自身に従属している 状態)上の全ての要素からなる集合である。ここで は下線を付した 3 個の主対角成分が 0.6 以上であ るので、強連結集合 $\left\{s_{2}, s_{3}, s_{5}\right\}$ が存在する。これを式 (7)のように1個の要素とみなすと $A$ は式(8)の ようになる。

$$
\begin{aligned}
& A_{c}=s_{3} s_{3} s_{5}\left[\begin{array}{ccc}
s_{2} & s_{3} & s_{5} \\
0.0 & 0.6 & 0.3 \\
0.4 & 0.0 & 0.7 \\
0.7 & 0.6 & 0.0
\end{array}\right]
\end{aligned}
$$

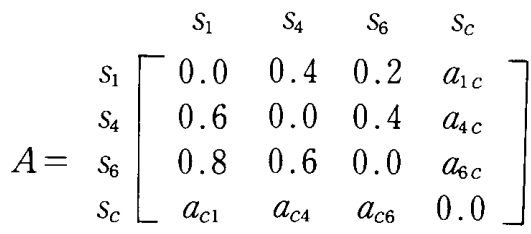

ここで、Aにおける強連結集合とそれに属さない 要素とのファジィ従属関係を示す代表值として最 小值または最大值いずれを用いても、図 $2(\mathrm{~b})$ に示 す構造が得られる ${ }^{16)}$ 。要求品質重要度は通常 $3 \sim 5$ 段階で求めるので、この場合は階層に対応して 4 段階の重要度とすればよい。

このように、ファジィ構造モデルでは、一対比 較行列の部分行列に問題があるため推移律が満た さず AHP を適用できない場合にも、循環するサ イクリックパスの存在を判定し、これを処理して 全体としての階層構造をそれなりに得ることがで き実用的である。また、一対比較の回数をある程
度削減して評価者の負担を軽減することもでき

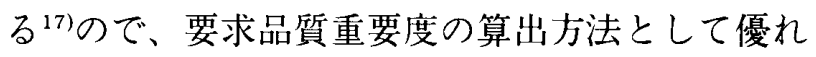
ているといえる。

\section{3 品質要素重要度の算出へのファジィ積分の適用}

品質展開は、マーケット・インの思考に立脚し たものであり、市場の要求の程度に応じて重点思 考していくことが必要である。そこで、市場の要 求である要求品質の重要度を、品質表の対応関係 を用いて、技術的管理特性である品質要素の重要 度に変換する。

この要求品質重要度を品質要素重要度の重要度 （ウェート）を変換する方法には、3〜 5段階評価な どで与えられる要求品質重要度と、表 3 に示すよ

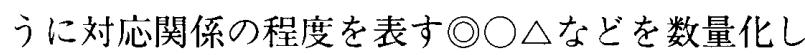
た値の積を求め、その值を縦に合計して品質要素 重要度を求める独立配点法などが考えられている。

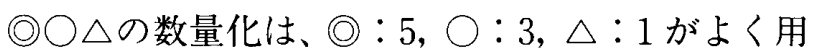
いられ、4:2:1 または $3: 2: 1$ という数量化も ある ${ }^{18)}$ 。すなわち、ある品質要素の重要度を $E$ 、 要求品質を $x_{i}$ とすると、独立配点法による $E$ は次 式で表される。

$$
E=\sum_{i=1}^{n} h\left(x_{i}\right) w_{i}
$$

ただし、 $h\left(x_{i}\right): x_{i}$ の対応関係の程度 $w_{i}: x_{i}$ の要求品質重要度

「100 円ライター」における要求品質として、 $x_{1}=$ 確実に着火する、 $x_{2}=$ 使いやすい、 $\cdots 、 x_{6}=$ 愛 着が持てるの 6 項目と品質要素「形状寸法」につ いて、対応関係の程度と要求品質重要度が表 4 の ように与えられたとき、「形状寸法」の品質要素重 要度 $E$ は、独立配点法によると次のように求ま る。

$$
E=0 \times 5+5 \times 5+3 \times 4+0 \times 3+3 \times 4+0 \times 3=49
$$

表3 品質表における対応関係づけ

\begin{tabular}{clc}
\hline 記号 & 意味 & 数量化 \\
\hline$\bigcirc$ & 強い対応 & 5 \\
$\bigcirc$ & 対応あり & 3 \\
$\triangle$ & 対応が予想される & 1 \\
\hline
\end{tabular}


このようにして、「100 円ライター」における品質 要素重要度を独立配点法を用いて算出した例を表 5 に示す。

しかし、顧客の要求自体が言葉で表現されるあ いまいなものであることに加えて、品質表におい て@○ 等で表される对応関係の程度は解析する 人間の主観によるあいまいなものである。これら を経験的な点数で置き換えて掛け合わせ、品質要 素ごとに集計する解析は便宜的であり、あいまい な值である。しかし、これを式(5)により掛け算を したり、その合計を求めたりする独立配点法は、 あいまいな值を比例尺度 (線形尺度)として扱って いることに加えて、重要度の非加法性 (相乗効果あ るいは相殺効果といった組み合わせ効果)が考虑 されていないという問題点がある19)。

要求品質重要度や対応関係の程度は主観による あいまいな值であるので、あいまいさを扱うファ ジィ理論の代表的な手法である「ファジィ積分」 により品質要素重要度を算出することが考えられ $3^{20,21)}$ 。ファジィ積分も幾つか提案されているが、 次のような $\lambda$ ファジィ測度によるファジィ積分
(菅野積分)が代表的である。

$X=\left\{x_{1}, x_{2}, \cdots, x_{n}\right\}$ とし、被積分関数 $h: \rightarrow$ $[0,1]$ を $h\left(x_{1}\right) \geq h\left(x_{2}\right) \geq \cdots \geq h\left(x_{n}\right)$ となるように、 $X$ の要素を並べ換える。 $F_{i}=\left\{x_{1}, x_{2}, \cdots, x_{n}\right\}$ とす るとファジィ測度 $g$ による $h$ の上のファジィ 積分は次式で与えられる。

$$
\begin{aligned}
f h \circ g & =\bigvee_{i=1}^{n}\left[h\left(x_{i}\right) \wedge g\left(F_{i}\right)\right] \\
\text { ただし、} & a \wedge b: \min \{a, b\} \\
& a \vee b: \max \{a, b\} \\
& \bigvee_{i=1}^{n} a_{i}: a_{1} \vee a_{2} \vee \cdots \vee a_{n}
\end{aligned}
$$

とくに入ーファジィ測度を考えると、F涪について、

$$
\begin{aligned}
g_{\lambda}\left(F_{i}\right) & =g^{i}+g_{\lambda}\left(F_{i-1}\right)+\lambda g^{i} g_{\lambda}\left(F_{i-1}\right) \\
& =\frac{1}{\lambda}\left[\prod_{k=1}^{n}\left(1+\lambda g^{k}\right)-1\right]
\end{aligned}
$$

のように構成できる。ただし、

\begin{tabular}{|c|c|c|c|c|c|c|c|}
\hline & $\begin{array}{c}\text { 確実に着火 } \\
\text { する } \\
x_{1}\end{array}$ & $\begin{array}{c}\text { 使いやすい } \\
x_{2} \\
\end{array}$ & $\begin{array}{c}\text { 安心して携 } \\
\text { 帯できる } \\
x_{3} \\
\end{array}$ & $\begin{array}{c}\text { 長い間使用 } \\
\text { できる } \\
x_{4} \\
\end{array}$ & $\begin{array}{c}\text { 良いデザイ } \\
\text { ンである } \\
x_{5}\end{array}$ & $\begin{array}{c}\text { 愛着が持て } \\
\text { る } \\
x_{6} \\
\end{array}$ & 計 \\
\hline 関連度 $h\left(x_{i}\right)$ & & $(0 / 5$ & $0 / 3$ & & $\bigcirc / 3$ & & \\
\hline 重要度 $w_{i}$ & 5 & 5 & 4 & 3 & 4 & 3 & 24 \\
\hline$h\left(x_{i}\right) w_{i}$ & 0 & 25 & 12 & 0 & 12 & 0 & 49 \\
\hline
\end{tabular}

$$
\begin{aligned}
g^{k} & =g_{\lambda}\left(\left\{x_{k}\right\}\right), \quad 0 \leq g^{k} \leq 1,1 \leq k \leq n \\
& =\frac{1}{\lambda}\left[\prod_{k=1}^{n}\left(1+\lambda g^{k}\right)-1\right] \quad\left(=g_{\lambda}(X)\right)
\end{aligned}
$$

\begin{tabular}{|c|c|c|c|c|c|c|c|c|}
\hline 要求品質展開表 & $\begin{array}{l}\text { 形 } \\
\text { 状 } \\
\text { 寺 } \\
\text { 法 }\end{array}$ & $\begin{array}{l}\text { 重 } \\
\text { 量 }\end{array}$ & $\begin{array}{l}\text { 耐 } \\
\text { 性 }\end{array}$ & $\begin{array}{l}\text { 着 } \\
\text { 性 }\end{array}$ & $\begin{array}{l}\text { 操 } \\
\text { 作 } \\
\text { 性 }\end{array}$ & $\begin{array}{l}\text { デ } \\
\text { ザ } \\
\vdots \\
\text { シ } \\
\text { 性 }\end{array}$ & $\begin{array}{l}\text { 話 } \\
\text { 題 } \\
\text { 性 }\end{array}$ & $\begin{array}{l}\text { 重 要 } \\
\text { 要求 } \\
\text { 度筫 }\end{array}$ \\
\hline 確実に着火する & & & $0 / 15$ & (c) $/ 25$ & $0 / 15$ & & & 5 \\
\hline 使いやすい & (a)/25 & (c) $/ 25$ & & & $0 / 15$ & & & 5 \\
\hline 安心して携帯できる & $0 / 12$ & $\triangle / 4$ & (O)/20 & $\mathrm{O} / 12$ & & & & 4 \\
\hline 長い間使用できる & & & (C)/15 & $0 / 9$ & $0 / 15$ & $\triangle / 9$ & & 3 \\
\hline 良いデザインである & $0 / 12$ & $0 / 12$ & & & & (2)/20 & $0 / 12$ & 4 \\
\hline 愛着が持てる & & & $\triangle / 3$ & & $\triangle / 3$ & $\bigcirc / 9$ & $(0 / 15$ & 5 \\
\hline 品質要素重要度 & 49 & 41 & 53 & 41 & 42 & 32 & 27 & \\
\hline
\end{tabular}

とする22)。

表4 独立配点法による品質要素「形状寸法」の重要度の算出例

表5 独立配点法による品質要素重要度の算出例 ${ }^{187}$ 
表6 品質要素の関連度と要求品質重要度の例

\begin{tabular}{l|cccccc}
\hline & $x_{1}$ & $x_{2}$ & $x_{3}$ & $x_{4}$ & $x_{5}$ & $x_{6}$ \\
\hline$h\left(x_{i}\right)$ & 0.0 & 1.0 & 0.6 & 0.0 & 0.6 & 0.0 \\
$g^{i}$ & 0.5 & 0.5 & 0.4 & 0.3 & 0.4 & 0.3 \\
\hline
\end{tabular}

表7ファジィ積分による品質要素重要度の算出例

\begin{tabular}{l|cccccc}
\hline & $x_{2}$ & $x_{3}$ & $x_{5}$ & $x_{1}$ & $x_{4}$ & $x_{6}$ \\
\hline$h\left(x_{i}\right)$ & 1.0 & 0.6 & 0.6 & 0.0 & 0.0 & 0.0 \\
$g^{i}$ & 0.5 & 0.4 & 0.4 & 0.5 & 0.3 & 0.3 \\
$g_{\lambda}\left(F_{i}\right)$ & 0.5 & 0.71 & 0.84 & 0.94 & 0.98 & 1.0 \\
$h\left(x_{i}\right) \wedge g_{\lambda}\left(F_{i}\right)$ & 0.5 & 0.6 & 0.6 & 0.0 & 0.0 & 0.0 \\
\hline
\end{tabular}

表 6 のように対応関係の程度 $h\left(x_{i}\right)$ と重要度 $g^{i}$ が与えられた場合、 $h\left(x_{i}\right)$ が降順になるように、 $X$ の要素を並べ換える。ー1<入を満たす実数解と して $\lambda=-0.945$ を得るので、表 7 よりファジィ 積分值は 0.6 と求まる。

この算出方法によれば、従来よく用いられてい る独立配点法における尺度および非加法性の問題 点が解決される。

なお、線形評価による算出值と同様に、要求品 質重要度の高い要求品質の対応関係の程度が大き ければ品質要素重要度も大きくなるが、両者は一

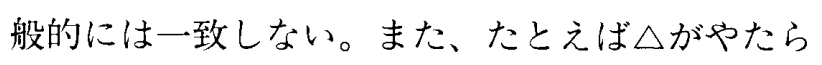
多い品質表のように、要求品質重要度が低く、対 応関係の程度も低い品質要素が多くある場合、線 形評価では評価值が大きめになりやすいが、ファ ジィ積分では影響を受けにくい。

さらに、要求品質が多い場合には、必要性係数

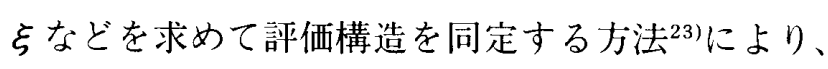
品質要素重要度の算出に不必要な要求品質を取り 除くことができる。

\section{9. 結 言}

以上、本稿では、品質保証あるいは品質保証シ ステムについて解説し、これにファジィ理論を応 用した例を紹介した。

すなわち、まず、品質保証の定義や品質管理と の関係に触れた上で、品質保証の歴史的発展やそ
の意義を述べた。さらに、品質保証と人というこ とを考察し、品質保証や品質管理へ人間の主観や あいまいさを取り込むことを積極的に行う必要が あること、および、その方法論としてファジィ理 論を応用する必要があることを論じた。そして、 品質保証のための品質機能展開へファジイ構造モ デルおよびファジィ積分を具体的に応用した例を 紹介した。

本稿で述べたように、品質保証の達成のために 品質管理を進めるのも人間であるし、マーケッ ト・インする相手である顧客も人間である。人間 の気持ちはあいまいであり、それがあいまいな言 葉で表現される。あいまいとくればファジィ理論 ということで、ファジィ理論を応用すれば品質管 理の「壁」のようなものも打破でき、アンチ $\mathrm{QC}$ 派 の実力者も洗脳することなく取り込めると思うの だが、いかがだろうか。

ファジィ理論に対する関心が必ずしも高いとは 言えない品質管理の分野において、本稿がファジ イ理論を導入する端緒となれば幸いである。

\section{謝 辞}

卓越した見識により本特集で品質保証システム を取り上げ、執筆の御推挙を賜りました筑波大学 鬼沢武久先生に敬意とともに感謝申し上げます。 また、ファジィ構造モデルについて御教唆を賜り ました桐蔭学園横浜大学田崎栄一郎先生ならびに 大東文化大学天笠美知夫先生に媣謝します。

なお、本稿は、平成 5 年度文部省科学研究費重 点領域研究 (課題番号：05220220)の補助を一部受 けている。記して謝意を表する。

\section{参考文 献}

1 ) 狩野紀昭：品質保証, 三浦新・狩野紀昭・津田義和・ 大橋靖雄編『TQC 用語辞典』, 日本規格協会, pp. 418-423， 1985

2 ) 高城 茂：商品開発における品質保証システムの 確立一総論一, 高城 茂編『商品開発と品質保 証』, フジテクノシステム, pp.418-437, 1993

3 ) 朝香鐵一、石川馨編：『品質保証ガイドブック』, 
川科技速出版社，pp.4-5，1974

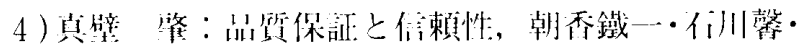

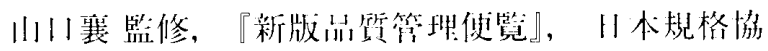
会, p.615, 1988

5 ) 前指过 3 , pp. 11-12

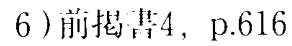

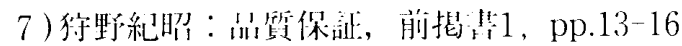

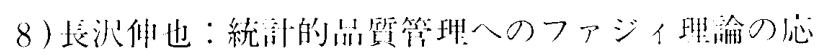

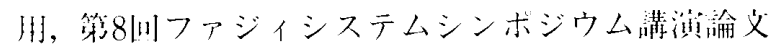
集、pp.157-160, 1992

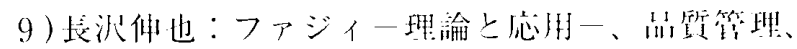
Vol.43, pp.1255-1261, 1992

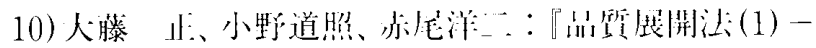

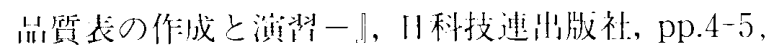
1990

11) 前掍書 1 , p.362

12)部指望 $10, p p .86-95$

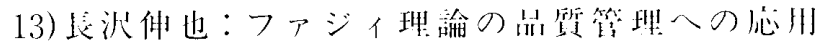
(6) - AHPとファジィ模僬モデルとの比較一，川

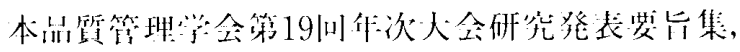
pp.49-52, 1989

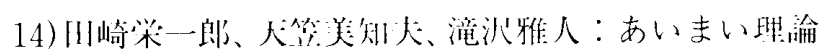
によるシステムの構暹モデル，川本オベレーショ

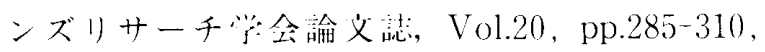
1977

15) Tazaki,E. and Amagasa,M. : Structural Modeling in a Class of Systems Using Fuzzy Sets Theory, Fuzzy Sets and Systems, Vol.2, pp.87103,1979

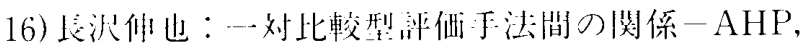

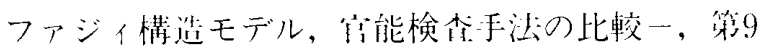
㺫ファジィシステムシンポジウム講演論文集、pp. 89-92, 1993

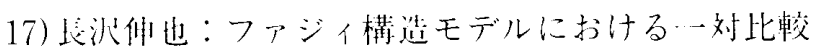
数の削減」j汒，籍7㺫ファジィシステムシンボジウ 么涶活谕文集, pp.319-322，1991

18) 胡指: 10 , pp. $106-114$

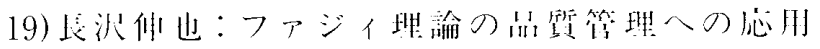

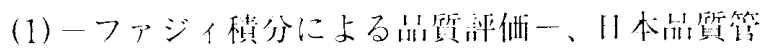

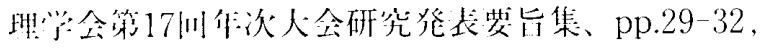
1987

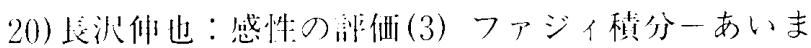

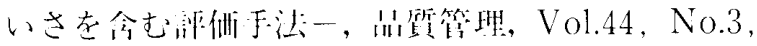
pp.71-78, 1993

21）上沃俳也：ファジィとは似か，講焇会「デザインの

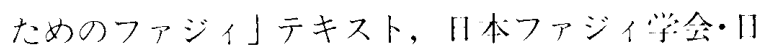
本デザイン筩全, pp.1-16, 1993

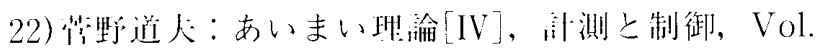
22, No.6, pp.50-55, 1972

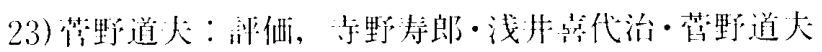
其緗『ファジィシステム人朋』, オーム社, pp.131 $-138,1987$

（1993年：9 J20月 受 付)

[专い合わせ先]

干180 東宗都武蔵野》境5-24-10

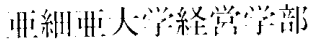
烄沃佃也 怔：0422-54-3111(代 [AWX : 0422-36-4857

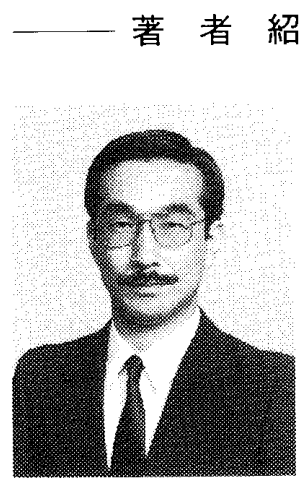

長沢伸也(かされんや゙

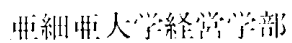

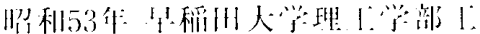

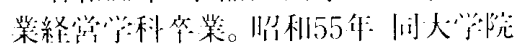

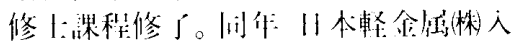

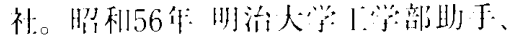

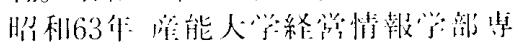

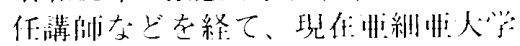

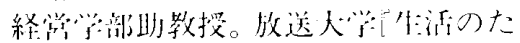

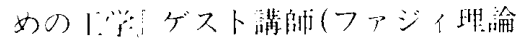

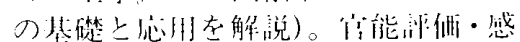

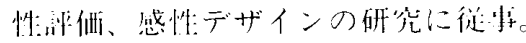

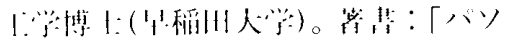

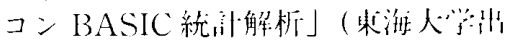
版全)「ノートバソコン・ッセンシ

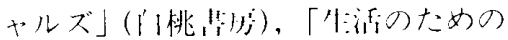

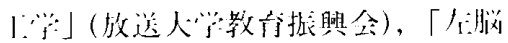
デザイニング」(海文裳) 他。川本デザ

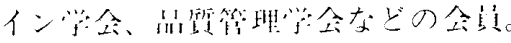

